\title{
PENGARUH MEDIA PEMBELAJARAN DAN METODE MENGAJAR TERHADAP HASIL BELAJAR PENDIDIKAN AGAMA ISLAM DI SMP SMP ISLAM TERPADU PURBAKTI CIAMPEA BOGOR
}

\author{
Fahrul Jamil \\ Visi Nusantara Maju \\ fahruljamil@gmail.com.
}

\begin{abstract}
Abstrak
Penelitian ini bertujuan untuk mengetahui pengaruh media pembelajaran dan metode mengajar dengan hasil belajar Pendidikan Agama Islam. Hipotesis yang akan diuji adalah pengaruh media pembelajaran terhadap prestasi belajar Pendidikan Agama Islam, pengaruh metode mengajar terhadap prestasi belajar Pendidikan Agama Islam dan pengaruh positif media belajar dan metode mengajar terhadap prestasi belajar Pendidikan Agama Islam. Penelitian ini dilakukan dengan metode survei dengan bentuk korelasional, populasi penelitian ini adalah seluruh siswa SMP Islam Terpadu (IT) Purbakti Ciampea Bogor yang berjumlah 435 siswa tahun pelajaran 2018/2019. Sampel diambil dengana teknik random sampling. Hasil penelitian ini menyimpulkan sebagai berikut ; Pertama, terdapat pengaruh positif media pembelajaran (X1) terhadap hasil belajar Pendidikan Agama Islam (Y. Kedua, terdapat pengaruh positif metode mengajar (X2) terhadap hasil belajar Pendidikan Agama Islam siswa (Y), Ketiga terdapat pengaruh positif media belajar (X1) dan metode mengajar (X2) terhadap hasil belajar Pendidikan Agama Islam siswa (Y). Hasil penelitian ini dapat berguna untuk memberikan pengertian dan pemahaman kepada para guru agar menggunakan media dalam proses pembelajaran dan menggunakan berbagai metode mengajar, agar materi pelajaran yang disamapaikan guru dapat tersrap dengan efektif dan baik oleh siswa, sehingga dapat meningkatkan hasil belajarnya, khususnya pada pelajaran Pendidikan Agama Islam (PAI).
\end{abstract}

Kata Kunci: Media pembelajaran, metode mengajar, hasil belajar dan Pendidikan Agama Islam

\section{PENDAHULUAN}

Pendidikan adalah usaha sadar dan terencana untuk mewujudkan suasana belajar dan proses pembelajaran agar peserta didik secara aktif mengembangkan potensi dirinya untuk memiliki kekuatan spiritual keagamaan, pengendalian diri, kepribadian, kecerdasan, akhlak mulia, serta keterampilan yang diperlukan diirnya, masyarakat, bangsa dan Negara. ${ }^{1}$ Pendidikan adalah pengalaman-pengalaman belajar terprogram dalam bentuk pendidikan formal dan non formal, dan informal di sekolah, dan di luar sekolah, yang berlangsung seumur hidup yang bertujuan optimalisasi

${ }^{1}$ Undang-undang N0. 20 tahun 2003, Sistem Pendidikan Nasional pasal 30 BAB I,Pasal 1 (Bandung: Fokusmedia, 2003), h. 3 
pertimbanagan kemampuan-kemampuan individu, agar di kemudian hari dapat memainkan peranan hidup secara tepat. ${ }^{2}$ Pendidikan sebagai sebuah bentuk kegiatan manusia dalam kehidupannya juga menempatkan tujuan sebagai sesuatu yang hendak dicapai, baik tujuan yang dirumuskan itu bersifat abstrak sampai rumusan-rumusan yang dibentuk secara khusus untuk memudahkan pencapaian tujuan yang lebih tinggi. Pendidikan Islam akan merupakan bagian integral dari sistem pendidikan nasional ${ }^{3}$. Kebutuhan akan pendidikan merupakan hal yang tidak bisa dipungkiri, bahkan semua itu merupakan hak semua warga Negara ${ }^{4}$, Tujuan pendidikan nasional suatu bangsa menggambarkan manusia yang baik menurut pandangan hidup yang dianut oleh bangsa itu, dan tujuan pendidikan sesuatu bangsa mungkin tidak akan sama dengan bangsa lainnya. ${ }^{5}$ Pendidikan Agama Islam adalah usaha sadar untuk menyiapkan siswa dalam meyakini, memahami, menghayati dan mengamalakan agama Islam melalui kegiatan bimbingan, pengajaran atau latihan dengan memperhatikan tuntutan adalah enghormati agama lain dalam hubungan kerukunan antar umat beragama dalam masyarakat untuk mewujudkan persatuan nasional ${ }^{6}$. Penjelasan tersebut dapat disimpulkan bahwa, Pendidikan Agama Islam adalah usaha bimbingan yang dilakukan secara sadar untuk mengarahkan anak didik mencapai kedewasaan baik jasmani maupun rohani sesuai dengan ajaran agama Islam dan pada akhirnya dapat menjadikan ajaran agama Islam sebagai pandangan hidupnya sehingga dapat mendatangkan keselamatan. Bertolak dari konsep manusia yang

2 Redja Mudiyaharjo, Pengantar Pendidikan: Sebuah Studi Awal Tentang DasardasarPenddidikan pada Umumnya dan Pendididkan di Indonesia, (Jakarta: PT Raja Grafindo Persada, 2002), Cet ke-2, h. 11

3 Sulfemi, W. B., \& Kamalia, Y. (2020). Jigsaw Cooperative Learning Model Using Audiovisual Media To Improve Learning Outcomes. JPsd (Jurnal Pendidikan Sekolah Dasar). 6 (1), 30-42. DOI: http://dx.doi.org/10.30870/jpsd.v6i1.4919

4 Sulfemi, Wahyu Bagja. (2016). Perundang-Undangan Pendidikan. Bogor : Program Studi Administrasi Pendidikan STKIP Muhammadiyah Bogor.

${ }^{5}$ Hasbullah, Dasar-dasar Ilmu Pendidikan, (Jakarta, PT Raja Grafindo Persada, 2005) Cet ke-4, h. 174

6 Sulfemi, W. B. (2018). Pengaruh Disiplin Ibadah Sholat, Lingkungan Sekolah, dan Intelegensi Terhadap Hasil Belajar Peserta Didik Mata Pelajaran Pendidikan Agama Islam. Edukasi: Jurnal Penelitian Pendidikan Agama dan Keagamaan. 16 (2), 166-178. DOI: 10.32729/edukasi.v16i2.474. 
bersifat integral-holistik, maka sistem pendidikan dalam Islam lebih berorientasi pada persoalan dunia dan ukhrawi sekaligus ${ }^{7}$, sehingga orientasi pendidikan ditekankan pada pengembangan seluruh potensi yang dimiliki oleh maunsia untuk menjalankan amanah dan tanggung jawabnya sebagai hamba khalifah di muka bumi ini. ${ }^{8}$

Hasil belajar adalah apa yang telah dapat diciptakan, hasil pekerjaan, hasil yang menyenangkan hati yang diperoleh dengan jalan keuletan kerja ${ }^{9}$. Jadi prestasi adalah penilaian pendidikan tentang perkembangan dan kemajuan siswa berkenaan dengan penguasaan bahan pelajaran yang disajikan kepada siswa. ${ }^{10}$ Hasil belajar merupakan hasil penilaian pendidikan tentang perkembangan dan kemajuan siswa berkenaan dengan penguasaan bahan pelajaran yang disajikan kepada siswa ${ }^{11}$. Hasil belajar adalah hal yang dicapai oleh siswa selama berlangsungnya proses belajar mengajar dalam jangka waktu tertentu, umumnya prestasi belajar dalam sekolah berbentuk pemberian nilai (angka) dari guru kepada siswa sebagai indikasi sejauhmana siswa telah menguasai materi pelajaran yang disampaikannya, biasanya prestasi belajar ini dinyatakan dengan angka, huruf, atau kalimat dan terdapat dalam periode tertentu ${ }^{12}$.

7 Sulfemi, Wahyu Bagja. (2019). Manajemen Pendidikan Berbasis Multi Budaya. Bogor : STKIP Muhammadiyah Bogor.

${ }^{8}$ Arsyad, Arsyad dan Wahyu Bagja Sulfemi, Pemberdayaan Individu Melalui Konsep Link And Match dalam Perspektif Pendidikan Islam. Prosiding Seminar Nasional, STKIP Muhammadiyah Bogor, 2017. h. 3

9 Sulfemi, Wahyu Bagja dan Yuliani, Nunung. (2019). Model Pembelajaran Contextual Teaching And Learning (CTL) Berbantu Media Miniatur Lingkungan Untuk Meningkatkan Hasil Belajar IPS. Edunomic. 7 (2). 73-84. DOI : 10.33603/ejpe.v7i2.1970.

${ }^{10}$ Sulfemi, W. B., \& Yuliana, D. (2019). Penerapan Model Pembelajaran Discovery Learning Meningkatkan Motivasi Dan Hasil Belajar Pendidikan Kewarganegaraan. Jurnal Rontal Keilmuan Pancasila dan Kewarganegaraan, 5(1), 17-30.Doi : http://dx.doi.org/10.29100/jr.v5i1.1021

11 Sulfemi, Wahyu Bagja. (2019). Model Pembelajaran Kooperatif Mind Mapping Berbantu Audio Visual Dalam Meningkatkan Minat, Motivasi dan Hasil Belajar IPS. Jurnal PIPSI (Jurnal Pendidikan IPS Indonesia), 4(1), 13-19. DOI: http://dx.doi.org/10.26737/jipips.v4i1.1204.

12 Sulfemi, Wahyu Bagja dan Setianingsih. (2018), Penggunaan Tames Games Tournament (TGT) Dengan Media Kartu Dalam Meningkatkan Hasil Belajar. Journal of Komodo Science Education (JKSE). 1 (1), 1-14. 
Dalam proses pendidikan, tidak terlepas dari kata belajar mengajar, dalam proses belajar mengajar, guru mempunyai tugas untuk mendorong, membimbing, dan memberi fasilitas belajar bagi siswa untuk mencapai tujuan. ${ }^{13}$ Guru mempunyai tanggung jawab untuk melihat segala sesuatu yang terjadi dalam kelas untuk membantu proses perkembangan siswa ${ }^{14}$.

Keduanya merupakan komponen utama dalam pendidikan. Belajar merupakan suatu proses yang menghasilkan perubahan ${ }^{15}$. Belajar juga merupakan suatu perubahan dalam tingkah laku dimana perubahan itu dapat mengarah kepada tingkah laku yang buruk. Suatu proses pembelajaran tidak luput dari kata mengajar, guru sebagai tenaga pendidik memfasilitasi serta memberi pengetatahuan terhadap peserta didik. ${ }^{16}$ Pembelajaran adalah suatu proses penanaman pengetahuan sebanyakbanyaknya dalam peserta didik. Agar proses pembelajaran berlangsung dengan baik, maka hendaknya guru memberikan materi pelajaran secara bervarasi, dapat menggunakan media/alat peraga sebagai alat bantu dalam mengajar serta menggunakan metode yang tepat. ${ }^{17}$ Jadi metode mengajar adalah suatu pengetahuan tentang cara-cara mengajar yang digunakan oleh seorang guru atau instruktur. ${ }^{18}$

Media pendidikan adalah cara atau proses yang digunakan untuk menyampaikan pesan dari sumber pesan kepada penerima pesan yang berlangsung dalam proses pendidikan ${ }^{19}$. Penggunaan media dalam proses pembelajaran cukup

${ }^{13}$ Arsyad, dan Wahyu Bagja Sulfem, Korelasi Penguasaan Materi Pembelajaran Oleh Guru Dengan Motivasi Belajar Siswa Mata Pelajaran Administrasi Perkantoran Di SMK Pelita Bogor. Jurnal edutecno STKIP Muhammadiyah Bogor, 2019. h. 12.

${ }^{14}$ Sulfemi, Wahyu Bagja dan Nurhasanah. (2018). Penggunaan Metode Demontrasi dan Media Audio Visual Dalam Meningkatkan Hasil Belajar Peserta Didik Mata Pelajaran IPS. Jurnal Pendas Mahakam. 3 (2). 151-158. https://jurnal.fkipuwgm.ac.id/index.php/pendasmahakam/article/view/229

15 Sulfemi, Wahyu Bagja dan Supriyadi, Dede. (2018). Pengaruh Kemampuan Pedagogik Guru dengan Hasil Belajar IPS. Edutecno 17 (1), 1-10.

${ }^{16}$ Purwanto, Ngalim, Psikologi Pendidikan, (Bandung : PT. Remaja Rosda Karya, 1998), h. 46

${ }^{17}$ Imran, Belajar dan Pembelajaran, ( Jakarta: Pustaka Jaya, 1996), h. 96 h. 127

18 Slameto, Belajar dan Faktor-faktor yang Mempengaruhinya, (Jakarta : Rineka Cipta, 2003),

${ }^{19}$ Sulfemi, Wahyu Bagja. (2017). Analisis Pengaruh Motivasi Dan Disiplin Terhadap Kinerja Guru (Studi Kasus di SMA Negeri 1 Pamijahan Kabupaten Kabupaten Bogor). Prosiding Seminar Nasonal STKIP Muhammadiyah Bogor. 1 (1), 342-357 
penting $^{20}$. Hal ini dapat membantu para siswa dalam mengembangkan imajinasi dan daya pikir serta kreatifitasnya ${ }^{21}$. Media pembelajaran yang digunakan oleh guru dalam proses pembelajaran memiliki andil untuk menjelaskan hal-hal yang abstrak dan menunjukan hal-hal yang tersembunyi. Ketidakjelasan atau kerumitan materi pembelajaran dapat dibantu dengan menghadirkan media sebagai perantara. Bahkan dalam hal-hal tertentu media dapat mewakili kekurangan guru dalam mengkomunikasikan materi pelajaran. ${ }^{22}$

Media pendidikan merupakan alat bantu yang digunakan dalam rangka mengefektifkan komunikasi antara siswa dengan guru. Adapun yang termasuk ke dalam media pendidikan yaitu gambar-gambar, diagram yang berhubungan dengan pembelajaran PAI ${ }^{23}$. Guru sebagai tenaga pendidik hendaknya mampu memilih media yang tepat dalam proses pengajaran ${ }^{24}$. Pengatahuan dan pemahaman yang cukup dalam memilih media, yang sesuai materi pelajaran akan menciptakan komunikasi yang seimbang antara siswa dengan guru. ${ }^{25}$ Untuk mencapai tujuan pembelajaran tidak mesti menggunakan media yang mahal, tetapai bagaimana guru itu pandai memanfaatkan media yang sederhana dan sudah tersedia di sekolah ${ }^{26}$. Salah satu pengertian dari media pendidikan yang cukup populer adalah alat, metode, dan teknik yang digunakan dalam rangka lebih mengefektifkan komunikasi dan

${ }^{20}$ Sulfemi, Wahyu Bagja., \& Desmiati, Z. (2018). Model Pembelajaran Missouri Mathematics Project Berbantu Media Relief Experience dalam Meningkatkan Hasil Belajar Siswa. PENDAS MAHAKAM: Jurnal Pendidikan Dasar,3(3), 232-245. https://jurnal.fkipuwgm.ac.id/index.php/pendasmahakam/article/view/269/173

${ }^{21}$ Sulfemi, Wahyu Bagja. (2018). Modul Manajemen Pendidikan Non Formal. Bogor: STKIP Muhammadiyah Bogor

22 Arsyad dan Sulfemi Wahyu Hagja, Metode Role Playing Berbantu Media Audio Visual Pendidikan Dalam Meningkatkan Belajar IPS. Jurnal Pendidikan Ilmu Pengetahuan Sosial Indonesia Volum 3 Nomor 2 bulan Maret 2018 Page 41 - 46

${ }^{23}$ Hamalik, Perencanaan Pengajaran Berdasarkan Sistem,( Jakarta Aksara: 2002), h. 154

24 Sulfemi, Wahyu Bagja dan Abdul Qodir. (2017). Hubungan Kurikulum 2013 Dengan Motivasi Belajar Peserta Didik Di SMK Pelita Ciampea. Edutecno 17 (2), 1-8.

25 Sulfemi, W. B., \& Minati, H. (2018). Meningkatkan Hasil Belajar Peserta Didik Kelas 3 SD Menggunakan Model Picture And Picture dan Media Gambar Seri. JPSD. 4 (2), 228- 242. DOI: http://dx.doi.org/10.30870/jpsd.v4i2.3857.

26 Sulfemi, Wahyu Bagja dan Lestari, Ayu Hopilatul. (2017). Korelasi Kompetensi Pedagogik Guru dengan Prestasi Belajar Mata Pelajaran IPS Di SMP Muhammadiyah Pamijahan Kabupaten Bogor. Edutecno. 16 (1), 1-16 
interaksi antara guru dan siswa dalam proses pendidikan dan pengajaran di sekolah. Oleh sebab itu media pendidikan adalah suatu bagian yang integral dari proses pendidikan. Idealnya, guru pada zaman milenial ini menjadi penggiat literasi agar memiliki cakrawala atau wawasan yang komprehensif. Sumber-sumber belajar sudah sangat banyak dan mudah ditemukan. Sumber yang berkaitan dengan tugas gurulah yang menjadi prioritas untuk dibaca. ${ }^{27}$

Sebelum menyusun perencanaan atau metode pengajaran, terlebih dahulu guru perlu mengenali kedudukan sistem pengajaran di sekolah. Pengenalan itu dimaksudkan agar guru atau calon guru memperoleh informasi yang relevan tentabng komponen sistem perencanaan pengajaran. Hal itu pada gilirannya dapat dijadikan sebagai bahan merancang sistem perencanaan pengajaran yang lebih baru. Dalam sistem pengajaran dikenal istilah prosedur pengajaran, meliputi; "prosedur pengajaran belajar dan motivasi, pengajaran konsep, pengajaran prinsip, pengajaran keterampilan, dan pengajaran kreatif. ${ }^{28}$

Strategi merancang sistem pengajaran adalah suatu rencana untuk mengerjakan prosedur merancang sistem secara efektif. Strategi dibutuhkanberhubungan dengan proses penerimaan ynag sesungguhnya amat kompleks. Dengan suatu strategi tertentu, perancang dapat menilai semua kemungkinan yang penting untuk dapat sampai pada keputusan atau penyelesaian dalam rangka mencapai tujuan yang telah ditetapkan. Ada tiga tahap dalam merencanakan desain suatu sistem pengajaran yaitu; (1) Menganalisis tuntutan sistem pengajaran, (2) Mendesain sistem pengajaran. (3) Mengevaluasi dampak sistem pengajaran ${ }^{29}$.

27 Arsyad, dan Wahyu Bagja Sulfemi, Pengaruh Kelompok Kerja Guru (KKG) Terhadap Peningkatan Kompetensi Pedagogik dan Kemampuan Menulis Karya Ilmiah. Jurnal Pendidikan Dasar Indonesia Volum 4 Nomor 2 bulan September 2019. h. 53 - 58

28 Sulfemi, Wahyu Bagja., \& Desmiati, Z. (2018). Model Pembelajaran Missouri Mathematics Project Berbantu Media Relief Experience dalam Meningkatkan Hasil Belajar Siswa. PENDAS MAHAKAM: Jurnal Pendidikan Dasar,3(3), 232-245. https://jurnal.fkipuwgm.ac.id/index.php/pendasmahakam/article/view/269/173

29 Sulfemi, Wahyu Bagja. (2018). Manajemen Kurikulum di Sekolah. Bogor : Visi Nusantara Maju 
Berdasarkan uraian di atas dapat dipahami bahwa profesi keguruan merupakan pekerjaan yang memerlukan kemampuan profesionalitas dalam melaksanakan tiga tugas utama yaitu, mendidik, mengajar, dan melatih. Mendidik berarti meluruskan dan mengembangkan nilai-nilai hidup (afektif). Mengajar berarti meneruskan dan mengembangkan ilmu pengetahuan dan teknologi (kognitif), sedangkan melatih berarti mengembangkan keterampilan-keterampilan pada siswa (psikomotorik).

Dengan demikan, Proses belajar mengajar di sekolah sebagai suatu proses yang merupakan suatu sistem dan tidak terlepas dari komponen-komponen lain yang saling berinteriaksi di dalamnya. Salah satu komponen dalam proses tersebut adalah media belajar dan metode atau perencanaan pengajaran. Pengajaran adalah bagian yang paling penting. Metode adalah berbagai cara yang teratur dan sistematis yang dilakukan dan ditempuh guru dalam memberi kesempatan kepada peserta didik untuk mendapatkan isi pelajaran yang mereka butuhkan. Media adalah seperangkat peralatan pendidikan dan pengajaran yang digunakan untuk membantu penyajian isi dan materi pelajaran kepada peserta didik agar mereka dapat mencapai tujuan. Evaluasi adalah seperangkat alat penilaian yang digunakan untuk menilai proses pembelajaran dan hasilnya.

Proses belajar mengajar merupakan inti dari prses pendidikan secara keseluruhan dengan guru sebagai pemegang peranan utama. Proses pembelajaran merupakan adalah suatu proses yang mengandung serangkaian interiakasi guru dan siswa atas dasar hubungan timbal balik yang berlangsung dalam situasi eduaktif untuk mencapai tujuan tertentu. Interiaksi antara guru dan siswa itu merupakan syarat utama bagi berlangsungnya proses pembelajaran, interiaksi tersebut mempunya arti yang luas, tidak sekedar hubungan antara guru dengan siswa, tetapiberupa interiaksi eduaktif. Dalam hal ini bukan hanya penyampaian pesan berupa materi pelajaran, melainkan penanaman sikap dan nilai pada siswa yang sedang belajar. Untuk lebih 
memahami pengertian proses pembelajaran, maka perlu mengetahui tugas-tugas guru dan kompetensi yang harus di miliki oleh guru prosesional ${ }^{30}$.

Guru merupakan profesi yang memerlukan keahlian khusus sebagai guru. Jenis profesi ini tidak dapat dilakukan oleh sembarang orang di luar bidang kependidikan, walaupun kenyataanya masih banyak guru yang mengajar di luar bidang kependidikan. Tugas guru sebagai profesi meliputi ; mendidik, mengajar, dan melatih. Mendidik berarti meneruskan dan mengembangkan nilai-nilai hidup. ${ }^{31}$ Mengajar berarti meneruskan dan mengembangkan ilmu pengetahuan dan teknologi. Sedangkan mealatih berarti mengembangkan keterampilan pada siswa.

\section{METODE PENELITIAN}

Tujuan penelitian ini adalah: (1) Mengetahui pengaruh antara media pembelajaran terhadap hasil belajar pendidikan agama siswa. (2) Mengetahui pengaruh antara metode mengajar terhadap hasil belajar pendidikan agama Islam siswa. (3) Mengetahui pengaruh media pembelajaran dan metode mengajar terhadap hasil belajar pendidikan agama Islam siswa. Penelitian dilaksanakan di Sekolah Menengah Pertama Islam Terpadu (SMP IT) Purbakti Ciampea Bogor, dengan jumlah siswa sebanyak 435 siswa.

\section{HASIL PENELITIAN}

Kegiatan penelitian sebagai suatu cara dalam memperoleh pengetahuanatau memecahkan masalah yang dihadapi yang dilakukan secara ilmiah, sistematis dan logis dalam menempuh langkah-langkah tertentu. ${ }^{32}$ Pada penelitian ini akan disajikan gambaran deskripsi data-data yang diperoleh dari penelitian yaitu data tentang media

30 Sulfemi, Wahyu Bagja. (2018). Hubungan Motivasi Belajar Dengan Hasil Belajar IPS Di SMP Kabupaten Bogor. Edutecno 18 (2), 1-8.

31 A. Tabrani Rusyan, Profesionalisme tenaga kependidikan, (Bandung : Yayasan Karya Sarjana Mandiri, 1990), h., 53

${ }^{32}$ Arsyad, Hubungan Antara Capaian Pembelajaran Dasar-Dasar Penelitian Dan Statistik Dengan Mutu Skripsi: Studi Analisis di STKIP Muhammadiyah Bogor. KHAZANAH PENDIDIKAN Jurnal Ilmiah Kependidikan, Volume XII, Nomor 2, Maret 2019.h. 99 
belajar diperoleh dengan menggunakan koesioner, dengan 4 pilihan yang disampaikan kepada responden untuk dipilih sesuai dengan keadaan diri responden. Data tentang metode pembelajaran juga diperoleh melalui koesioner yang disampaikan secara langsung kepada responden dengan 4 pilihan untuk dipilih yang paling sesuai dengan keadaan dirinya. Sedangkan hasil belajar pendidikan agama Islam siswa diambil melalui hasil ujian semester genap tahun ajaran 2019/2020 kelas VII s.d IX.

\section{Hasil belajar Pendidikan Agama Islam}

Untuk instrument hasi belajar PAI diambil melalui hasi ujian semester genap siswa tahun pelajaran 2019/2020, dengan standar nilai terendah 60 dan tertinggi 90. Dari jumlah data sebanyak 40 responden untuk variabel hasil belajar PAI ini diperoleh rentang 30, interval 5, banyak interval 6, median 75 dan modus 75 serta rerata 73,5 .

\section{Media belajar}

Untuk instrumen perhatian media belajar diambil melalui koesioner, dengan 4 pilihan jawaban yang paling sesuai dengan kondisi siswa. Dari jumlah data sebanyak 40 responden untuk varibel perhatian media belajar ini diperoleh nilai terndah skor 55, dan nilai tertinggi skor 85 , interval 5, banyak interval 6 , rerata 68,95, median 75, dan modus 65 .

\section{Metode mengajar}

Berdasarkan data metode mengajar, dengan nilai berkisar 45 sampai 80, dengan skor terendah 60, dan tertinggi 90. Secara keseluruhan skor yang diperoleh dari hasil minat baca diperoleh rentang 25 , interval 5 , banyak interval 6, median 80, modus 75, rerata 81,37. Rangkuman persamaan regresi dan hasil uji keberartian seperti table di bawah. 
Tabel 4. Rangkuman persamaan regresi

\begin{tabular}{|l|cc|}
\hline \multicolumn{1}{|c|}{ Regresi } & \multicolumn{2}{|c|}{ Persamaan Regresi } \\
\hline $\mathrm{Y}$ atas X1 & $\tilde{Y}$ & $=6,42+0,53 \mathrm{X} 1$ \\
$\mathrm{Y}$ atas X2 & $\tilde{Y}$ & $=5,21+0,48 \mathrm{X} 2$ \\
$\mathrm{Y}$ atas X1 dan X2 & $\tilde{\mathrm{Y}}$ & $=5,20+0,10+0,59 \mathrm{X} 2$ \\
\hline
\end{tabular}

Tabel 5. Hasil uji linearitas dan keberartian regresi

\begin{tabular}{|l|c|c|l|}
\hline \multicolumn{1}{|c|}{ Linearitas } & $\begin{array}{c}\text { F- } \\
\text { hitung }\end{array}$ & F-tabel & \multicolumn{1}{|c|}{ Kesimpulan Linearitas } \\
\hline $\mathrm{Y}$ atas X1 & 6,22 & $(1 / 38 ; 0,05) 4,10$ & Fh> Ft Regresi Signifikan \\
Y atas X2 & 4,62 & $(1 / 38 ; 0,05) 4,10$ & Fh > Ft Regresi Signifikan \\
Y atas X1, X2 & 4,63 & $(2 / 37 ; 0,03) 3,25$ & Fh > Ft Regresi Signifikan \\
\hline
\end{tabular}

Dari hasil regresi disajikan pada tabel 4 dan 5 tersebut diatas dapat diartikan bahwa; (1) Terbukti teruji ada pengaruhn fungsional antara variabel X1 dengan $\mathrm{Y}$, karena persamaan regresi $\tilde{Y}=6,42+0,53 \mathrm{X} 1$, berdasarkan hasil uji linearitas regresi persamaan dimaksud linier dan berdasarkan hasil uji regresi persamaan dimaksud signifikan. (2) Terbukti teruji ada pengaruh fungsional antara variabel $\mathrm{X} 2$ dengan $\mathrm{Y}$, karena persamaan regresi $\tilde{Y}=5,21+0,48 X 2$, berdasarkan hasil uji linearitas regresi persamaan dimaksud linier dan berdasarkan hasil uji regresi persamaan dimaksud signifikan. (3) Terbukti teruji ada pengaruh fungsional antara variabel $\mathrm{X} 1$ dan $\mathrm{X} 2$ dengan $\mathrm{Y}$, karena persamaan regresi $\tilde{Y}=5,20+0,10+0,59 \mathrm{X} 2$ berdasarkan hasil uji linearitas regresi persamaan dimaksud linier dan berdasarkan hasil uji regresi persamaan dimaksud juga signifikan. Rangkuman hasil perhitungan koefisien korelasi dan koefisien dan hasil uji signifikan koefisien korelasi sebagai berikut ;

Tabel 6. Hasil perhitungan koefisien korelasi

\begin{tabular}{|c|c|}
\hline Korelasi & Koefisien korelasi \\
\hline $\mathrm{r}_{\mathrm{y} 1}$ & 0,811 \\
$\mathrm{r}_{\mathrm{y} 2}$ & 0,430 \\
$\mathrm{R}_{\mathrm{y} .12}$ & 0,350 \\
\hline
\end{tabular}


Tabel 7. Hasil uji signifikan koefisien korelasi

\begin{tabular}{|c|c|c|c|}
\hline Korelasi & T-hitung & T-tabel & Kesimpulan koefisien korelasi \\
\hline $\mathrm{r}_{\mathrm{y} 1}$ & 3,45 & $(0,95,38) 1,69$ & T-hit > table, koef korelasi signifikan \\
$\mathrm{r}_{\mathrm{y} 2}$ & 2,36 & $(0,95,38) 1,69$ & T-hit > table, koef korelasi signifikan \\
$\mathrm{R}_{\mathrm{y} .12}$ & 4,68 & $(0,05 ; 2 / 37) 3,32$ & T-hit > tabel, koef korelasi signifikan \\
\hline
\end{tabular}

Dari hasil perhitungan analisis korelasi seperti disajikan pada tabel 7 diatas dapat diartikan : Pertama, terdapat pengaruh positif yang signifikan antara variabel $\mathrm{X} 1$ dengan variabel $\mathrm{Y}$, dengan adanya korelasi $\mathrm{r} \mathrm{y} 1=3,45$ dengan hasil uji koefisien korelasi yang signifikan pada $\alpha=5 \%$ serta diperjelas bahwa $60 \%$ variasi Y dipengaruhi oleh $\mathrm{X}_{1}$. kedua, terdapat pengaruh positif yang signifikan antara variabel $\mathrm{X}_{2}$ dengan variabel $\mathrm{Y}$, dengan adanya korelasi $\mathrm{r}$ y2 $=2,36$ dengan hasil uji koefisien korelasi yang signifikan pada $\alpha=5 \%$ serta diperjelas bahwa $60 \%$ variasi Y dipengaruhi oleh $\mathrm{X}_{2}$. Ketiga, terdapat pengaruh positif yang signifikan antara variabel $\mathrm{X}_{1}$ dan $\mathrm{X}_{2}$ dengan variabel $\mathrm{Y}$, dipertegas adanya korelasi $\mathrm{R}$ y.12 $=4,68$ dengan hasil uji koefisien korelasi yang signifikan pada $\alpha=5 \%$ serta diperjelas bahwa $70 \%$ variasi $\mathrm{Y}$ dipengaruhi oleh $\mathrm{X}_{1}$ dan $\mathrm{X}_{2}$.

\section{PEMBAHASAN}

Penelitian ini ingin mengetahui pengaruh media belajar dan metode mengajar, baik secara sendiri-sendiri maupun secara bersama-sama dengan hasil belajar pendidikan agama Islam siswa. Media pembelajaran secara sendiri memiliki pengaruh yang signifikan dengan variabel hasil belajar pendidikan agama Islam siswa, hal ini dapat dilihat melalui korelasi. Dari korelasi tersebut dapat diambil suatu pengertian bahwa perhatian media belajar memiliki pengaruh dengan tinggi rendahnya hasil belajar pendidikan agama Islam siswa. Guru sebagai salah satu 
komponen dalam pendidikan harus ditingkatkan terus kompetensi dan keterampilannya untuk menghasilkan proses pembelajaran yang bermutu kelas. ${ }^{33}$

Faktor metode mengajar juga memiliki pengaruh dengan hasil belajar pendidikan agama Islam siswa, sehingga dengan kenyataan itu, untuk mendapatkan nilai atau hasil belajar PAI yang baik diperlukan metode mengajar guru yang baik. Dengan demikian, metode mengajar guru untuk meningkatkan pengetahuan agama Islam siswa sangat diperlukan. Dari hasil penelitian ini membuktikan bahwa perhitungan regresi ganda untuk pengujian hipotesis $\mathrm{Y}$ atas $\mathrm{X}_{1}$ dan $\mathrm{X}_{2}$ terbukti bahwa secara bersama-sama (Media belajar dan metode mengajar) berhubungan secara signifikan terhadap Y (hasil belajar pendidikan agama Islam siswa). Hal ini membuktikan bahwa siswa yang ingin mendapatkan hasil belajar PAI yang baik, tidak hanya di dukung oleh media belajar atau kompetensi guru menguasai metode mengajar, tetapi juga harus ada keduanya yang menjadi faktor penentu untuk meninmgkatkan prestasi belajar pendidikan agama Islam di sekolah.

Tanpa adanya media pembelajaran dan metode mengajar, maka sulit untuk bisa meningkatkan hasil belajar siswa, demikian juga halnya dengan siswa yang ingin mendapatkan hasil belajar pendidikan agama Isam yang baik, kalau tidak ada dukungan dari proses pembelajaran yang menggunakan media belajar dan disertai dengan rasa kemampuan guru dalam mengajar dengan memahami metode mengajar dengan baik, maka sulit untuk mendapatkan pemahaman, pengetahauan dan hasil belajar pendidikan agama Islam yang baik. Arsyad, Salahahudin, bahawa Faktor yang mendasari pencapaian tujuan PAI adalah faktor internal, yaitu memiliki keinginan yang kuta, dengan minat yang kuat mendorong siswa untuk mendalami materi pelajaran lebih serius. ${ }^{34}$

33 Arsyad, dan Wahyu Bagja Sulfemi Pengembangan Keprofesian Berkelanjutan (PKB) Bagi Guru Melalui Program Induksi Guru Pemula (PIGP). Prosiding Seminar Nasional, STKIP Muhammadiyah Bogor, 2018. h. 6.

34 Arsyad dan Salahudin, Hubungan Kemampuan Membaca Al Qur'an Dan Minat Belajar Siswa Dengan Hasil Belajar Pendidikan Agama Islam (PAI). EDUKASI: Jurnal Penelitian Pendidikan Agama dan Keagamaan, p-ISSN: 1693-6418, e-ISSN: 2580-247.h. 188. 
Berdasarkan uraian diatas, sangat jelas bahwa media belajar dan metode mengajar secara sendiri-sendiri sebagai modal utama yang maing-masing berdiri sendiri secara signifikan dapat meningkatkan hasil belajar pendidikan agama Islam siswa SMP. Dengan demikian, siswa yang ingin memperoleh hasil belajar pendidikan agam Islam yang baik, maka paling tidak harus mendapatkan disertai dengan media pembelajaran yang tepat, dan juga harus disertai dengan kemampuan guru dalm menerapkan metode-metode mengajar yang bervariasi agar supaya dapat memahamidan mengerti materi pelajaran dengan efektif, dan pada akhirnya dapat meningkatkan nilai atau hasil belajar pendidikan agama Islam siswa di sekolah

\section{SIMPULAN}

Konsisiten dengan rumusan masalah dan tujuan penelitian yang telah ditetapkan dari seluruh proses dan hasil penelitian, dapat ditarik beberapa simpulan sebagai berikut; (1) Siswa dalam proses pembelajaran disertai dengan media belajar yang tepat, terutama di sekolah, mempunyai kecenderungan untuk memperoleh hasil belajar pendidikan agam Islam di sekolah. Kesimpulan tersebut sesuai dengan landasan teori telah dikemukakan diatas, mediapembelajaran memberikan kemudahan bagi siswa dalam menerima dan mengerti materi pelajaran yang disampaikan, terutama dalam pendidikan agama Islam di sekolah, sehingga mendapatkan hasil belajar Pendidikan Agama Islam yang tinggi. (2) Terdapat pengaruh yang signifikan antara metode mengajar dengan hasil belajar pendidikan agama Islam siswa. Kesimpulan tersebut sesuai dengan landasan teori telah dikemukakan diatas, bahwa metode mengajar yang baik, terutama pada guru pendidikan Islam akan membawa siswa cepat menangkap materi pelajaran yang dapat meningkatkan wawasan dan pengetahuan PAI siswa, sehingga mendapatkan hasil belajar Pendidikan Agama Islam yang tinggi. (3) Hasil peneitian ini membuktikan adanya pengaruh positif antara variabel yang ada dalam penelitian.

Berdasarkan hasil penelitian diatas, ada beberapa implikasi yang dapat dikemukakan terutama dalam meningkatkan hasil belajar pendidikan agama Islam 
siswa, dan cara meningkatkan hasil belajar Pendidikan Agama Islam siswa serta upaya yang akan dilakukan yaitu: Pertama, adanya korelasi antara media pembelajaran dengan hasi belajar Pendidikan Agama Islam siswa. Dalam upaya meningkatkan hasil belajar Pendidikan Agama Islam siswa, maka pihak sekolah dan guru agama Islam perlu terus melengkapi berbagai bentuk-bentuk media belajar di sekolah, sebab dengan media belajar yang tepat sesuai dengan materi pembelajaran, dapat mengantarkan siswa memperoleh hasil belajar Pendidikan Agama Islam di sekolah dengan baik. Kedua, adanya korelasi antara metode mengajar dengan hasil belajar Pendidikan Agama Islam siswa. Sebagai upaya meningkatkan hasil belajar pendidikan agam Islam siswa, maka guru agama Islam perlu memhamai berbagai mavam metode mengajar, terutama pada metode pengajaran pendidikan agama Islam, sebab metodemengajar yang baik dapat meningkatkan pengetahuan, wawasan dan hasil belajar PAI siswa di sekolah. Karena tanpa adanya metode mengajar yang tepat, maka kemampuan siswa menangkap materi pelajarana pendidikan agama Islam akan terbatas. Ketiga, adanya indeks korelasi pada semua variabel bebas secara bersamasama terhadap variabel terikat. Hal ini menandakan bahwa media belajar dan metode mengajar secara bersama-sama perlu terus ditingkatkan demi meningkatkan hasil belajar siswa pada Pendidikan Agama Islam. Karena tanpa adanya media pembelajaran dan penguasaan guru terhadap metode mengajar, maka rasanya sulit bagi siswa untuk meningkatkan pengetahuan keagamaan, hal ini akan berdampak pada rendahnya keinginan pada siswa untuk mempelajari dan mengamalkan ajaran agama Islam.

\section{DAFTAR PUSTAKA}

Arsyad, Arsyad dan Salahudin, Salahudin, Hubungan Kemampuan Membaca Al Qur'an Dan Minat Belajar Siswa Dengan Hasil Belajar Pendidikan Agama Islam (PAI). EDUKASI: Jurnal Penelitian Pendidikan Agama dan Keagamaan, September 2018.

Arsyad, Arsyad, Hubungan Antara Capaian Pembelajaran Dasar-Dasar Penelitian Dan Statistik Dengan Mutu Skripsi: Studi Analisis di STKIP 
Muhammadiyah Bogor. KHAZANAH PENDIDIKAN Jurnal Ilmiah Kependidikan, Volume XII, Nomor 2, Maret 2019.

Arsyad, Arsyad dan Sulfemi Wahyu Hagja, Metode Role Playing Berbantu Media Audio Visual Pendidikan Dalam Meningkatkan Belajar IPS. Jurnal Pendidikan Ilmu Pengetahuan Sosial Indonesia Volum 3 Nomor 2 bulan Maret 2018.

Arsyad, Arsyad dan Sulfemi, Wahyu Bagja, Pengaruh Kelompok Kerja Guru (KKG) Terhadap Peningkatan Kompetensi Pedagogik dan Kemampuan Menulis Karya Ilmiah. Jurnal Pendidikan Dasar Indonesia Volum 4 Nomor 2 bulan September 2019.

Arsyad, Arsyad dan Sulfem Wahyu Bagja, Korelasi Penguasaan Materi Pembelajaran Oleh Guru Dengan Motivasi Belajar Siswa Mata Pelajaran Administrasi Perkantoran Di SMK Pelita Bogor. Jurnal edutecno STKIP Muhammadiyah Bogor, 2019.

Arsyad, Arsyad dan Wahyu Bagja Sulfemi, Pengembangan Keprofesian Berkelanjutan (PKB) Bagi Guru Melalui Program Induksi Guru Pemula (PIGP). Prosiding Seminar Nasional, STKIP Muhammadiyah Bogor, 2018.

Arsyad, Arsyad dan Wahyu Bagja Sulfemi, Pemberdayaan Individu Melalui Konsep Link And Match dalam Perspektif Pendidikan Islam. Prosiding Seminar Nasional, STKIP Muhammadiyah Bogor, 2017.

Depdiknas R I., UU. NO. 14 Tahun 2005, Guru dan Dosen, Jakarta; Biro Hukum dan Organisasi Sekretaris Jenderal Diknas RI, 2005.

Hamalik, Omar, Perencanaan Pengajaran Berdasarkan Sistem, Jakarta Aksara: 2002.

Hasbullah, Dasar-dasar Ilmu Pendidikan, Jakarta, PT Raja Grafindo Persada, 2005.

Imron, Ali, Pembinaan Guru di Indonesia. Jakarta: PT. Dunia Pustaka Jaya 16 Jurnal Pendidikan Penabur - No.04 / Th.IV/ Juli 2005.

Purwanto, Ngalim, Psikologi Pendidikan. Bandung: Remaja Rosdakarya, 1991.

Rusyan, A. Tabrani, Profesionalisme tenaga kependidikan. Bandung:Yayasan Karya Sarjana Mandiri, 1990.

Redja Mudiyaharjo, Pengantar Pendidikan: Sebuah Studi Awal Tentang DasardasarPenddidikan pada Umumnya dan Pendididkan di Indonesia. Jakarta: PT Raja Grafindo Persada, 2002.

Sulfemi, Wahyu Bagja. (2016). Perundang-Undangan Pendidikan. Bogor : Program Studi Administrasi Pendidikan STKIP Muhammadiyah Bogor. 
Sulfemi, Wahyu Bagja. (2017). Analisis Pengaruh Motivasi Dan Disiplin Terhadap Kinerja Guru (Studi Kasus di SMA Negeri 1 Pamijahan Kabupaten Kabupaten Bogor). Prosiding Seminar Nasonal STKIP Muhammadiyah Bogor. 1 (1), 342-357.

Sulfemi, Wahyu Bagja dan Abdul Qodir. (2017). Hubungan Kurikulum 2013 Dengan Motivasi Belajar Peserta Didik Di SMK Pelita Ciampea. Edutecno 17 (2), 1 8 .

Sulfemi, Wahyu Bagja dan Lestari, Ayu Hopilatul. (2017). Korelasi Kompetensi Pedagogik Guru dengan Prestasi Belajar Mata Pelajaran IPS Di SMP Muhammadiyah Pamijahan Kabupaten Bogor. Edutecno. 16 (1), 1-16.

Sulfemi, Wahyu Bagja., \& Desmiati, Z. (2018). Model Pembelajaran Missouri Mathematics Project Berbantu Media Relief Experience dalam Meningkatkan Hasil Belajar Siswa. PENDAS MAHAKAM: Jurnal Pendidikan Dasar, 3(3), 232-245. https://jurnal.fkipuwgm.ac.id/index.php/pendasmahakam/article/view/269/173

Sulfemi, Wahyu Bagja. (2018). Modul Manajemen Pendidikan Non Formal. Bogor: STKIP Muhammadiyah Bogor

Sulfemi, W. B., \& Minati, H. (2018). Meningkatkan Hasil Belajar Peserta Didik Kelas 3 SD Menggunakan Model Picture And Picture dan Media Gambar Seri. JPSD. 4 (2), 228- 242. DOI: http://dx.doi.org/10.30870/jpsd.v4i2.3857.

Sulfemi, Wahyu Bagja., \& Desmiati, Z. (2018). Model Pembelajaran Missouri Mathematics Project Berbantu Media Relief Experience dalam Meningkatkan Hasil Belajar Siswa. PENDAS MAHAKAM: Jurnal Pendidikan Dasar,3(3), 232-245. https://jurnal.fkipuwgm.ac.id/index.php/pendasmahakam/article/view/269/173

Sulfemi, Wahyu Bagja. (2018). Manajemen Kurikulum di Sekolah. Bogor : Visi Nusantara Maju

Sulfemi, Wahyu Bagja. (2018). Hubungan Motivasi Belajar Dengan Hasil Belajar IPS Di SMP Kabupaten Bogor. Edutecno 18 (2), 1-8.

Sulfemi, W. B. (2018). Pengaruh Disiplin Ibadah Sholat, Lingkungan Sekolah, dan Intelegensi Terhadap Hasil Belajar Peserta Didik Mata Pelajaran Pendidikan Agama Islam. Edukasi: Jurnal Penelitian Pendidikan Agama dan Keagamaan. 16 (2), 166-178. DOI: 10.32729/edukasi.v16i2.474.

Sulfemi, Wahyu Bagja dan Setianingsih. (2018), Penggunaan Tames Games Tournament (TGT) Dengan Media Kartu Dalam Meningkatkan Hasil Belajar. Journal of Komodo Science Education (JKSE). 1 (1), 1-14. 
Sulfemi, Wahyu Bagja dan Nurhasanah. (2018). Penggunaan Metode Demontrasi dan Media Audio Visual Dalam Meningkatkan Hasil Belajar Peserta Didik Mata Pelajaran IPS. Jurnal Pendas Mahakam. 3 (2). 151-158. https://jurnal.fkipuwgm.ac.id/index.php/pendasmahakam/article/view/229.

Sulfemi, Wahyu Bagja dan Supriyadi, Dede. (2018). Pengaruh Kemampuan Pedagogik Guru dengan Hasil Belajar IPS. Edutecno 17 (1), 1-10.

Sulfemi, Wahyu Bagja. (2019). Manajemen Pendidikan Berbasis Multi Budaya. Bogor : STKIP Muhammadiyah Bogor.

Sulfemi, Wahyu Bagja dan Yuliani, Nunung. (2019). Model Pembelajaran Contextual Teaching And Learning (CTL) Berbantu Media Miniatur Lingkungan Untuk Meningkatkan Hasil Belajar IPS. Edunomic. 7 (2). 73-84. DOI : 10.33603/ejpe.v7i2.1970.

Sulfemi, W. B., \& Yuliana, D. (2019). Penerapan Model Pembelajaran Discovery Learning Meningkatkan Motivasi Dan Hasil Belajar Pendidikan Kewarganegaraan. Jurnal Rontal Keilmuan Pancasila dan Kewarganegaraan, 5(1), 17-30.Doi : http://dx.doi.org/10.29100/jr.v5i1.1021.

Sulfemi, Wahyu Bagja. (2019). Model Pembelajaran Kooperatif Mind Mapping Berbantu Audio Visual Dalam Meningkatkan Minat, Motivasi dan Hasil Belajar IPS. Jurnal PIPSI (Jurnal Pendidikan IPS Indonesia), 4(1), 13-19. DOI: http://dx.doi.org/10.26737/jipips.v4i1.1204.

Sulfemi, W. B., \& Kamalia, Y. (2020). Jigsaw Cooperative Learning Model Using Audiovisual Media To Improve Learning Outcomes. JPsd (Jurnal Pendidikan Sekolah Dasar). 6 (1), 30-42. DOI: http://dx.doi.org/10.30870/jpsd.v6i1.4919.

Slameto, Belajar dan Faktor-Faktor Yang Mempengaruhinya. Yogyakarta: Bina Cipta, 1995.

Syaiful Bahri Djamarah, Prestasi Belajar dan Kompetensi Guru. Surabaya: Usaha Nasional, 1994. 